\title{
The Enhancement Difference of Eight Grade Students' Mathematical Problem-Solving Ability
}

\author{
Adrina Fauza \\ Post Graduate Mathematics Education \\ State University of Medan \\ Indonesia \\ fauzaadrina@gmail.com
}

\author{
E. Elvis Napitupulu \\ Mathematics Education \\ State University of Medan \\ Indonesia
}

\author{
Nerli Khairani \\ Mathematics Education \\ State University of Medan \\ Indonesia
}

\begin{abstract}
The aims of this research are to analyze: the difference of the improvement mathematical problem-solving ability between students taught by guided discovery learning with the students taught by expository learning, and the interaction between mathematics learning with students 'early mathematical abilities on students' mathematical problemsolving abilities. This study is quasi experiment study. The population of this study was the 8th grade students of MTsN Stabat. Then, the sample was taken by using random sampling method, with VIII-1 were chosen as experiment 1 class and VIII2 as experiment 2 class. The experiment 1 class was treated by using guided discovery learning while the experiment 2 class was by using expository learning. The result of this study shows that: there is enhancement difference of student mathematical problem-solving ability taught by guided discovery learning and taught by expository learning, and there is no interaction between the learning and the initial ability (high, medium, low) on students' mathematical problem-solving abilities.
\end{abstract}

Keywords— problem-solving ability, guided discovery learning

\section{INTRODUCTION}

Mathematics is one lesson that has an important role as a science, even named "the queen of science". Fast mathematical development can be seen from the many concepts that are applied in everyday life and able to simplify and solve problems in real life. [1] Johnson \& Mycklebust stated that mathematics is a symbolic language for expressing quantitative and spatial relationships that make it easier for humans to think about solving problems. By learning mathematics there will be a structured process in understanding facts and relationships related to mathematics, and the truth can be proven. [2] Cornelius stated that mathematics important because: 1) the way of thinking is clear and logical, 2) means to solve problems in everyday life, 3) a means of recognizing patterns of relationships and generalizing experiences, 4) a means to develop creativity, and 5) a means to increase awareness of cultural developments.

Problems are things that are never separated from life, so problem solving becomes an important factor in the process of learning mathematics, and mathematical problem solving is one of the abilities students must have in learning mathematics. [3] NCTM sets 5 standard mathematical abilities that students must have, there are: problem solving, reasoning, communication, connection, and representation.
[4] Napitupulu stated that problem solving is one of the most important forms of learning in mathematics, Through problem solving students can practice and integrate concepts, theorems and skills that have been learned. Furthermore, he also said that teaching students to solve problems allows students to be more analytical in making decisions in life. [5] Ruseffendi stated that problem solving skills are very important in mathematics, not only for those who will later explore or study mathematics, but also for those who will apply it in other fields of study and in everyday life.

The importance of mathematical problem solving skills is in line with NCTM which places problem solving in the first order of the central purpose of mathematics education, but the reality that occurs shows that what is expected has not been achieved. The results of the observations obtained indicate the fact that students' mathematical problem solving abilities are still relatively low.

There are several factors that are the causes of students' low mathematical problem solving abilities, among them is the learning process that has not been able to provide enthusiasm and desire for students to learn, so learning is still one-way, there is no interaction between teacher and students in the learning process, and never been taught how students must solve problems, so students are unusual to solving problems in the form of problem solving.

One learning model that can be used to improve students' mathematical problem solving skills is a guided discovery learning model. [6] Eggen stated guided discovery are a teaching approach where the teacher gives students specific topic examples and guides students to understand the topic.

Research results from [7] Verawati, Napitupulu, and Rajagukguk that there are differences in the improvement of problem solving skills and student learning motivation taught by problem-based learning and guided discovery learning Likewise with the results of the study of [8] Dede shows that the improvement of mathematical problem solving abilities of students who take part in learning with guided discovery methods is better than students who learn using scientific approaches. 


\section{THEORETICAL FRAMEWORK}

\section{A. Guided Discovery}

First, According to [9] Bruner (Dahar), learning discovery is in accordance with the search for knowledge actively by humans and by itself gives the best results, and in learning discovery, the purpose of learning is not only to achieve knowledge. Knowing is a process not a product. In other words, learning is also a process of discovery. According to [6] Eggen, guided findings are a teaching approach where the teacher gives students specific topic examples and guides students to understand the topic.

According to [10] Slavin (Hosnan), in learning with discovery, students are encouraged to learn largely through their own active involvement with concepts and principles, and the teacher encourages students to have experience and conduct experiments that allow them to find principles for themselves. In this case the discovery occurs when students in mental processes such as observing, classifying, making guesses, measuring, explaining, drawing conclusions and so on to find some concepts or principles. Students can also make estimates (conjecture), formulate a hypothesis and find the truth using inductive processes or deductive processes, make observations, and make exploration.

In addition, according to [11] Kuhlthau, guided discovery is a learning approach where students find and use diverse sources of information and ideas to improve understanding of a problem, topic or issue. Students are encouraged to learn mostly through their own active involvement with concepts and principles. The characteristics of guided discovery can be more clearly seen from the six principles outlined by [11] Kuhlthau as follows: a) Children learn by being actively engaged in and reflecting on an experience, b) Children learn by building on what they already know, c) Children develop higher order thinking through guidance at critical points in the learning process, d) Children have different ways and modes of learning, e) Children learn through social interaction with others, f) Children learn through instruction and experience in accord with their cognitive development.

Indicators will be used in this research according to [10] Hosnan: (a) giving of problem and stimulus, (b) problem statement, (c) collecting data, (d) data processing, (e) verification, and (f) generalization.

\section{B. Mathematical Problem-Solving Ability}

In learning mathematics, not all questions are a problem for a student but can be a problem for another student. It is related to Polya's opinion, the problem must be "challenge" and an unknown routine procedure. The routine procedure is that the problem can predict, the formula is known, and with one or two steps the question can complete usually.

One of the abilities expected by students to learn mathematics is the problem-solving ability. According to [3] NCTM, solving problems is not only for purpose in learning mathematics but at the same time is the main tool for learning. According to [4] Napitupulu stated problem-solving is one of the most important forms of learning in mathematics. Through problem-solving students can practice and integrate concepts, theorems, and skills that have been learning. Furthermore, he also said that teaching students to solve problems allows students to be more analytical in making decisions in real life. By studying problem-solving in mathematics, then students are able to solve relevant problems, unusual problems using different patterns, able to have new knowledge in every problem solving, so that they have confidence in solving problems both outside the learning process.

The focus of mathematical problem-solving abilities used according to [12] Charles, Lester, \& O'Daffer (Szetala \& Nicol), that is: (1) understanding problem; (2) solving the problem; (3) answer the problem. With the achievement indicator to be used is: (1) write down what is known and asked; (2) choose the right strategy by formulating a plan that can produce the right solution; and (3) implement strategies to solve problems

\section{RESEARCH QUESTION}

1. Is there a difference in increasing the mathematical problem-solving abilities of students who get guided discovery learning with students who get expository learning?

2. Is there an interaction between the learning model and students 'initial mathematical abilities towards students' mathematical problem-solving abilities?

\section{RESEARCH METHOD}

This study was categorized into quasi-experiment research. The population in this study we're all VIII grade students of MTSn Stabat and the sample is class VIII- 1 students as the experiment 1 class and class VIII-2 as the experiment 2 class, each class with 30 students. The experiment 1 class in this study will be giving a guided discovery learning model, and the experiment 2 class will be giving a expository learning.

\section{DATA ANALYSIS, RESULT AND DISCUSSION}

The main purpose of this study is to determine the differences in the increase in mathematical problem-solving abilities of students who get guided discovery learning and students who get expository learning. Furthermore, it will be seen whether there is an interaction between learning model and students 'initial mathematical abilities on students' mathematical problem-solving abilities.

TABLE 1. NORMALITY TEST RESULT PRE TEST AND POST TEST SCORE

\begin{tabular}{|cc|r|r|r|r|r|r|}
\hline \multirow{2}{*}{ Grup } & \multicolumn{2}{|c|}{ Kolmogorov-Smirnov ${ }^{\mathrm{a}}$} & \multicolumn{3}{|c|}{ Shapiro-Wilk } \\
\cline { 3 - 8 } & & Statistic & df & Sig. & Statistic & Df & Sig. \\
\hline \multirow{2}{*}{ Pre } & Exp1 & .118 & 30 & $.200^{*}$ & .949 & 30 & .156 \\
& Exp2 & .113 & 30 & $.200^{*}$ & .972 & 30 & .589 \\
\hline Post & Exp1 & .148 & 30 & .093 & .942 & 30 & .104 \\
& Exp2 & .126 & 30 & $.200^{*}$ & .933 & 30 & .060 \\
\hline
\end{tabular}

a. Lilliefors Significance Correction

*. This is a lower bound of the true significance. 
From the results of Table 1 shows that the probability value (sign) of the pretest and posttest for each learning model is greater than 0.05 . This means that is $\mathrm{HO}$ accepted and $\mathrm{Ha}$ is rejected, which means that data on mathematical problemsolving abilities of students come from populations that are normally distributed.

TABLE 2 HOMOGENITY TEST RESULT FOR PRE TEST AND POST TEST SCORE

Test of Homogeneity of Variance

\begin{tabular}{|cc|r|r|r|r|}
\hline & $\begin{array}{c}\text { Levene } \\
\text { Statistic }\end{array}$ & \multicolumn{1}{c|}{ df1 } & \multicolumn{1}{c|}{ df2 } & \multicolumn{1}{c|}{ Sig. } \\
\hline Pretes & Based on Mean & .460 & 1 & 58 & .501 \\
$\mathrm{t}$ & Based on Median & .444 & 1 & 58 & .508 \\
& Based on Median and & .444 & 1 & 56.672 & .508 \\
& with adjusted df & & & & \\
& Based on trimmed mean & .442 & 1 & 58 & .509 \\
\hline Postte & Based on Mean & 4.293 & 1 & 58 & .073 \\
st & Based on Median & 3.325 & 1 & 58 & .073 \\
& Based on Median and & 3.325 & 1 & 53.338 & .074 \\
& with adjusted df & & & & \\
& Based on trimmed mean & 4.249 & 1 & 58 & .044 \\
\hline
\end{tabular}

From the results of Table 2, the probability values (sign) of pretest and posttest are higher than 0.05. This means that Ho is accepted and $\mathrm{Ha}$ is rejected which means data mathematical problem-solving abilities of students come from the same or homogeneity group of data variances.

TABLE 3 RECAPITULATION OF N-GAIN RESULT OF MPSA

\begin{tabular}{|c|c|c|c|}
\hline \multirow{2}{*}{ Indicator } & \multirow{2}{*}{$\begin{array}{c}\text { Statistical } \\
\text { Data }\end{array}$} & $\begin{array}{c}\text { Experiment 1 } \\
\text { Class }\end{array}$ & $\begin{array}{c}\text { Experiment 2 } \\
\text { Class }\end{array}$ \\
\hline \multirow{2}{*}{ High } & $\overline{\boldsymbol{\pi}}$ & 0,59 & 0,43 \\
\hline \multirow{2}{*}{ Medium } & SD & 0,05 & 0,05 \\
\cline { 2 - 4 } & $\overline{\boldsymbol{x}}$ & 0,52 & 0,37 \\
\hline \multirow{2}{*}{ Low } & SD & 0,09 & 0,09 \\
\hline \multirow{2}{*}{ All } & $\overline{\boldsymbol{x}}$ & 0,44 & 0,32 \\
\cline { 2 - 4 } & SD & 0,04 & 0,1 \\
\hline & $\overline{\boldsymbol{x}}$ & 0,55 & 0,37 \\
\hline
\end{tabular}

Based on Table 3, it appears overall that the average n-gain the results of the problem-solving ability tests of students in the experiment 1 class are 0,55 and experiment 2 class are 0,37 , which means the experiment 1 class is higher than the experiment 2 class, that is $0,55>0,37$. Based on the [13] Hake category, improvement of mathematical problemsolving abilities of students who get guided discovery learning is to include in the medium category $(0,3<\mathrm{g} \leq 0,7)$, so also those who get expository learning. It can be seen that the high average n-gain results of tests on students' mathematical problem solving abilities in the experiment 1 class and the experiment 2 class indicate that there is an increase the problem-solving ability of students in the experiment 1 class is higher than students' mathematical problem-solving abilities in the experiment 2 class. Thus there is a difference in improvement between students who get guided discovery learning and get expository learning.

In the experiment 1 class and experiment 2 class, students with high KAM obtained an average increase in mathematical problem-solving ability (n-gain) that was greater than students with medium KAM and low KAM. Students in the experiment 1 class get an average increase in mathematical problemsolving ability (n-gain) that is greater than the experiment 2 class students for each pair of KAM categories.

TABLE 4 RESULT OF CALCULATION CLASS EXPERIMENT 1 REGRESSION COEFFICIENS

Coefficients $^{\mathrm{a}}$

\begin{tabular}{|c|c|c|c|c|c|}
\hline \multirow[t]{2}{*}{ Model } & \multicolumn{2}{|c|}{$\begin{array}{l}\text { Unstandardized } \\
\text { Coefficients }\end{array}$} & $\begin{array}{l}\text { Standardized } \\
\text { Coefficients }\end{array}$ & \multirow[b]{2}{*}{$\mathrm{T}$} & \multirow[b]{2}{*}{ Sig. } \\
\hline & B & Std. Error & Beta & & \\
\hline $\begin{array}{cc}\text { (Consta } \\
\text { nt })\end{array}$ & 43.206 & 6.885 & & 6.275 & .000 \\
\hline Pretest & 675 & .130 & .700 & 5.180 & .000 \\
\hline
\end{tabular}

a. Dependent Variable: Postes

TABLE 5 RESULT OF CALCULATION CLASS EXPERIMENT 2 REGRESSION COEFFICIENS

Coefficients

\begin{tabular}{|c|c|c|c|c|c|}
\hline \multirow[t]{2}{*}{ Model } & \multicolumn{2}{|c|}{$\begin{array}{l}\text { Unstandardized } \\
\text { Coefficients }\end{array}$} & \multirow{2}{*}{$\begin{array}{c}\begin{array}{c}\text { Standardized } \\
\text { Coefficients }\end{array} \\
\text { Beta }\end{array}$} & \multirow[b]{2}{*}{$\mathrm{T}$} & \multirow[b]{2}{*}{ Sig. } \\
\hline & $\mathrm{B}$ & Std. Error & & & \\
\hline 1 (Constant) & 23.579 & 7.734 & & 3.049 & .005 \\
\hline Pretest & .902 & .153 & .743 & 5.880 & .000 \\
\hline
\end{tabular}

a. Dependent Variable: Posttest

Based on Table 4 and table 5, coefficients regression problem-solving ability for experiments 1 class $\mathrm{Y}_{\mathrm{E} 1}=43,206+$ $0,675 \mathrm{X}_{\mathrm{E} 2}$ and coefficients regression problem-solving ability for experiment 2 class $Y_{\mathrm{E} 2}=23,579+0,902 \mathrm{X}_{\mathrm{E} 2}$

TABLE 6 ANOVA FOR MPSA INDEPENDENCE TEST EXPERIMENT 1 CLASS

\begin{tabular}{|rc|c|r|r|r|r|}
\hline \multicolumn{1}{|c|}{ Model } & $\begin{array}{c}\text { Sum of } \\
\text { Squares }\end{array}$ & df & \multicolumn{1}{c|}{$\begin{array}{c}\text { Mean } \\
\text { Square }\end{array}$} & F & Sig. \\
\hline 1 & Regression & 261.520 & 1 & 261.520 & 26.837 & $.000^{\mathbf{a}}$ \\
& Residual & 272.855 & 28 & 9.745 & & \\
& Total & 534.375 & 29 & & & \\
\hline
\end{tabular}

a. Predictors: (Constant), Pretest

b. Dependent Variable: Posttest

From the results of the calculations in Table 6 above, for problem-solving capabilities obtained $\mathrm{F}$ calculate $=26,837$ with sign $0,000^{\mathrm{a}}$. In this case, the sign value less than 0.05 $\left(0,000^{\mathrm{a}}<0,05\right)$, so there is enough evidence to reject Ho and $\mathrm{Ha}$ is accepted. In other words, the regression coefficient of students' mathematical problem-solving abilities in the experiment 1 class is meaningful which means there is a linear relationship between the pretest and the posttest of students (independent).

TABLE 7 ANOVA FOR MPSA INDEPENDENCE TEST EXPERIMENT 2 CLASS

\begin{tabular}{|rc|r|r|r|r|r|}
\hline \multicolumn{1}{|c|}{ Model } & $\begin{array}{c}\text { Sum of } \\
\text { Squares }\end{array}$ & \multicolumn{1}{|c|}{ Df } & $\begin{array}{c}\text { Mean } \\
\text { Square }\end{array}$ & \multicolumn{1}{|c|}{ F } & Sig. \\
\hline 1 & Regression & 619.803 & 1 & 619.803 & 34.580 & $.000^{\mathrm{a}}$ \\
& Residual & 501.863 & 28 & 17.924 & & \\
Total & 1121.667 & 29 & & & \\
\hline
\end{tabular}

a. Predictors: (Constant), Pretest

b. Dependent Variable: Posttest 
From the results of the calculations in Table 7 above, for problem-solving capabilities obtained $\mathrm{F}$ calculate $=34,580$ with (sign) $0,000^{\mathrm{a}}$. In this case, the sign value less than 0,05 $\left(0,000^{\mathrm{a}}<0,05\right)$, so there is enough evidence to reject Ho and $\mathrm{Ha}$ is accepted. In other words, the regression coefficient of students' mathematical problem-solving abilities in the experiment 2 class is meaningful which means there is a linear relationship between the pretest and the posttest of students (independent).

TABLE 8. ANOVA FOR MPSA REGRESSION LINEARITY TEST EXPERIMENT 1 CLASS

\begin{tabular}{|c|c|c|c|c|c|c|c|}
\hline & & & $\begin{array}{l}\text { Sum of } \\
\text { Squares }\end{array}$ & Df & $\begin{array}{l}\text { Mean } \\
\text { Square }\end{array}$ & F & Sig. \\
\hline \multirow{5}{*}{$\begin{array}{l}\text { Post } \\
* \\
\text { Pre }\end{array}$} & $\begin{array}{c}\text { Betwee } \\
n\end{array}$ & $\begin{array}{l}\text { (Combin } \\
\text { ed) }\end{array}$ & 402.113 & $\overline{6}$ & 67.019 & 11.654 & .900 \\
\hline & Groups & Linearity & 261.520 & 1 & 261.520 & 45.478 & .004 \\
\hline & & $\begin{array}{c}\text { Deviatio } \\
n \text { from } \\
\text { Linearity }\end{array}$ & 140.593 & 5 & 28.119 & 3.890 & .390 \\
\hline & Withir & Groups & 132.262 & 23 & 5.751 & & \\
\hline & & tal & 534.375 & 29 & & & \\
\hline
\end{tabular}

From the results of the calculations in Table 8 above, for problem-solving capabilities obtained $\mathrm{F}$ calculate $=3,890$ with sign 0,390 . In this case the sign value greater than $0.05(0,300$ $>0,05)$, then there is not enough evidence to reject Ho so Ho is accepted and $\mathrm{Ha}$ is rejected which means the experiment 1 class regression model is linear.

TABLE 9. ANOVA FOR MPSA REGRESSION LINEARITY TEST EXPERIMENT 2 CLASS:

\begin{tabular}{|c|c|c|c|c|c|c|c|}
\hline \multicolumn{8}{|c|}{ ANOVA Table } \\
\hline & & & $\begin{array}{l}\text { Sum of } \\
\text { Squares }\end{array}$ & Df & $\begin{array}{l}\text { Mean } \\
\text { Square }\end{array}$ & $\mathrm{F}$ & Sig. \\
\hline \multirow[t]{5}{*}{$\begin{array}{l}\text { Post * } \\
\text { Pre }\end{array}$} & $\begin{array}{l}\text { Betwe } \\
\text { en }\end{array}$ & $\begin{array}{l}\text { (Combin } \\
\text { ed) }\end{array}$ & 872.812 & 8 & 109.102 & 9.207 & .000 \\
\hline & $\begin{array}{c}\text { Group } \\
\mathrm{s}\end{array}$ & Linearit & 619.803 & 1 & 619.803 & 52.303 & .000 \\
\hline & & $\begin{array}{c}\text { Deviatio } \\
\text { n from } \\
\text { Linearit } \\
y\end{array}$ & 253.009 & 7 & 36.144 & 3.050 & .022 \\
\hline & Within & Groups & 248.854 & 21 & 11.850 & & \\
\hline & & otal & 1121.667 & 29 & & & \\
\hline
\end{tabular}

From the results of the calculations in Table 9 above, for problem-solving capabilities obtained $\mathrm{F}$ calculate $=3,050$ with sign 0,22 . In this case the sign value higher than 0.05 (3.05 > 0.05), then there is not enough evidence to reject Ho so Ho is accepted and $\mathrm{Ha}$ is rejected which means the experiment 1 class regression model is linear. In other words, there is a relationship between the results of the pretest and the posttest of the experiment 2 class students which can be shown by linear regression models with regression equations for problem-solving abilities $\mathrm{Y}_{\mathrm{E} 2}=23,579+0,902 \mathrm{X}_{\mathrm{E} 2}$, so did the experiment 1 class.
TABLE 10 ANOVA FOR THE SIMILARITIES OF TWO REGRESSION MODELS

\begin{tabular}{|c|c|c|c|c|c|c|}
\hline \multicolumn{2}{|r|}{ Model } & $\begin{array}{l}\text { Sum of } \\
\text { Squares }\end{array}$ & Df & $\begin{array}{c}\text { Mean } \\
\text { Square }\end{array}$ & $\mathrm{F}$ & Sig. \\
\hline \multirow[t]{3}{*}{1} & Regression & 1463.533 & 1 & 1463.533 & 50.902 & $.000^{\mathrm{a}}$ \\
\hline & Residual & 1667.613 & 58 & 28.752 & & \\
\hline & Total & 3131.146 & 59 & & & \\
\hline
\end{tabular}

From the results of the calculations in Table 10 above, for problem-solving capabilities obtain $\mathrm{F}$ calculate $=50,902$ with sign value. $0,000^{\mathrm{a}}$. In this case, the sign value lower than 0,05 $\left(0,000^{\mathrm{a}}<0,05\right)$, so there is reject Ho and Ha is accepted which means that the linear regression model between the experiment 1 class and the experiment 2 class is not the same or significantly different.

TABLE 11 ANACOVA FOR REGRESSION MODEL ALIGNMENT

\begin{tabular}{|c|c|c|c|c|}
\hline Class & SST $_{x}$ & SST $_{y}$ & SPT & SST $_{x}$ (adj) \\
\hline $\begin{array}{c}\text { Discovery } \\
\text { Learing }\end{array}$ & 5960.967 & 739.783 & -664.400 & 665.73035 \\
\hline $\begin{array}{c}\text { Expository } \\
\text { Learning }\end{array}$ & 9984.200 & 1525.000 & 2615.750 & 839.70242 \\
\hline Total & $\begin{array}{c}15945.16 \\
7\end{array}$ & 2264.783 & 1951.350 & 1505.43 \\
\hline A & $\mathbf{B}$ & $\mathbf{F}^{*}$ & $\mathbf{F}$ & $\mathbf{H}_{\mathbf{0}}$ \\
\hline 1505.43 & 2025.980 & 1.364 & 4.001 & Accepted \\
\hline
\end{tabular}

From the results of the calculations in Table 11 for problem-solving capabilities obtained $F$ calculate 1,364. Based on $\mathrm{F}$ table, $\mathrm{F}$ table $=4,001$ for $\alpha=5 \%$. In this case $\mathrm{F}$ calculate lower than F table $(1,364<4,001)$, so Ho is accepted, this means that both linear regression models for the experiment 2 class and experiment 1 class are linier. Because both regression models are linear and do not coincide, it can be concluded that there are differences in the learning outcomes of the experiment class and the experiment 2 class.

Furthermore, the calculation results of the hypothesis testing analysis with the SPSS 18 program in Table 12 below:

Based on Table 12 was seen that interaction between learning (learning model) and initial mathematical ability (IMA), with sign value 0,080 . In this case the sign value greater than $0.05(0,80>0,05)$, Ho is accepted and $\mathrm{Ha}$ is rejected, which means there is no interaction between the learning model and IMA on mathematical problem solving ability. 
TABLE 12. RESULT ANACOVA MATHEMATICAL PROBLEM SOLVING ABILITY

Tests of Between-Subjects Effects

Dependent Variable:posttest

\begin{tabular}{|c|r|r|r|r|r|}
\hline Source & $\begin{array}{c}\text { Type III Sum of } \\
\text { Squares }\end{array}$ & Df & $\begin{array}{c}\text { Mean } \\
\text { Square }\end{array}$ & F & Sig. \\
\hline Corrected & $1752.813^{\mathrm{a}}$ & 5 & 350.563 & 3.734 & .080 \\
Model & & & & & \\
Intercept & 184902.135 & 1 & 184902.13 & 7244.05 & .000 \\
& & & 5 & 0 & \\
Learning * & 1752.813 & 5 & 350.563 & 3.734 & .080 \\
IMA & & & & & \\
Error & 1378.333 & 54 & 25.525 & & \\
Total & 329843.750 & 60 & & & \\
Corrected & 3131.146 & 59 & & & \\
Total & & & & & \\
\hline
\end{tabular}

a. R Squared $=.560($ Adjusted R Squared $=.519)$

This shows that no effect together between learning model and IMA. For more details no interaction between the learning model and IMA on mathematical problem solving ability, graphically can be seen in the following figure:

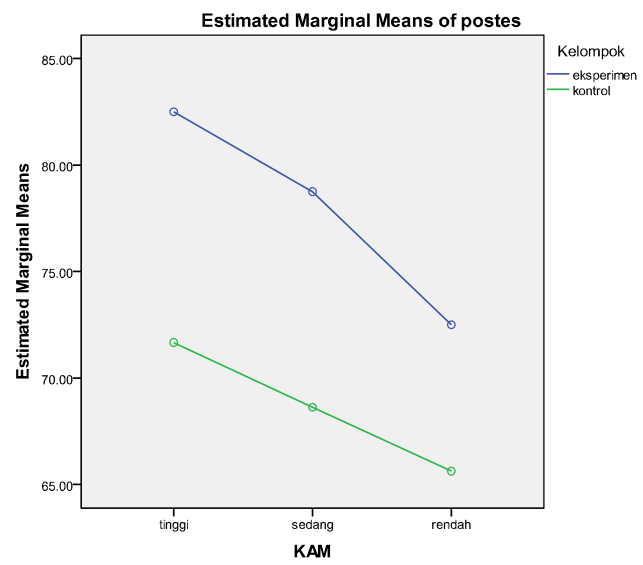

Fig. 1. Graph of Interaction between Learning Model and KAM Students' Mathematical Problem Solving Ability

Based on the result study, it makes big difference on students which are taught by guided discovery learning and on students which are taught by expository learning. The students which are taught by guided discovery learning will be more active in giving question, thinking and working in constructing certain knowledge. Otherwise, the students which are taught by expository learning they tend to accept and listen teacher's explanation. The teacher doesn't demand the students to be more active in thinking, discussing, and working.

Besides, the students which are taught by expository learning only know certain knowledge and the students which are taught by guided discovery learning will understand more and really master the knowledge. This case is the cause of students enhancement which are taught by guided discovery learning is higher than students enhancement which are taught by expository learning.

\section{CONCLUSION}

Based on the results of the analysis, learning mathematics both with guided discovery learning and expository learning can be summarized as follows:

1. There is enhancement difference of student mathematical problem solving ability taught by guided discovery learning and taught by ilearning.

2. There is no interaction between learning model and initial mathematical ability (high, medium, low) towards improving students' mathematical problem solving abilities.

\section{REFERENCES}

[1] Johnson, D. J. \& Mycklebust, H. R. 1967. Learning Disabilities. New York: Grume \& Stratton

[2] Cornelius, M. L. 1982. Teaching Mathematics. [Online] http://books.google.co.id/books/about/Teaching_Mathematics.html?id= ZKE9AAAAIAAJ\&redir_esc=y, 1 Desember 2017

[3] National Council of Teachers of Mathematics. 2000. Principles and Standards for School Mathematics. Reston: NCTM

[4] Napitupulu, E. E. 2008. Mengembangkan Strategi dan Kemampuan Siswa Memecahkan Masalah Matematik. Pythagoras, 2008 (4): 2. DOI: http://dx.doi.org/10.21831/pg.v4i2.557

[5] Dahar, R.W. 1989. Teori-teori Belajar. Jakarta: Erlangga

[6] Eggen, P. (2012). Strategi dan Model Pembelajaran Mengajar Konten dan Keterampilan Berpikir, Edisi 6. Jakarta: PT Indeks

[7] Verawati. Napitupulu, E. E. \& Rajagukguk, W. The Difference in the Improvement of Problem Solving Ability and Students Motivation Who Taught by Problem Based Learning and Discovery Learning. American Journal of Educational Research. 2018, 6(12), 1609-1617. DOI: 10.12691/education-6-12-4

[8] Dede. 2016. Penerapan Metode Penemuan Terbimbing Untuk Meningkatkan Kemampuan Pemecahan Masalah Matematis, Kemampuan Komunikasi Matematis, dan Analisis Kemandirian Belajar Siswa SMA. Thesis. UNPAS.

[9] Dahar, R.W. 2011. Teori-teori Belajar dan Pembelajaran. Bandung: Gelora Aksara Pratama

[10] Hosnan, M. 2014. Pendekatan Saintifik dan Konstekstual dalam Pembelajaran Abad 21: Kunci Sukses Implementasi Kurikulum 2013. Bogor: Ghalia Indonesia.

[11] Kuhlthau, C. C., Maniotes, L. K. \& Caspari, A. K. 2007. Guided Inqury: Learning in The 21st Century School. Wesport, CT: Libraries Unlimited

[12] Szetela, W. \& Nicol, W. 1992. Evaluating Problem Solving in Mathematics. New York: Cambridge University Press.

[13] Hake, R. (1998). Relationship of Individual Student Normalized Learning Gains in Mechanics with Gender, High-School Physics, and Pretest Scores on Mathematics and Spatial Visualization. Physics Education Research Conference. Boise, Idaho. 